\title{
Anatomical and Histological Characterization of the Digestive Canal of the Golden Kingklip (Genypterus blacodes)
}

\author{
Caracterización Anatómica e Histológica del Canal Digestivo \\ del Congrio Dorado (Genypterus blacodes)
}

Salinas, P. ${ }^{1}$; Serrano, E. ${ }^{2}$; Sánchez, J. C. ${ }^{3}$ \& Godoy, M. ${ }^{4}$

SALINAS, P.; SERRANO, E.; SÁNCHEZ, J. C. \& GODOY, M. Anatomical and histological characterization of the digestive canal of the golden kingklip (Genypterus blacodes). Int. J. Morphol., 38(3):677-682, 2020.

SUMMARY: Given the importance of the Golden kingklip (Genypterus blacodes) as an alternative to the production of salmonid species for worldwide diversification of aquaculture this study researched the morpho-histology of the digestive canal, providing a uniform nomenclature and basic information to support their nutritional management in captive conditions. The objective was to describe the normal morphology of the digestive canal. Twelve wild specimens were collected and dissected. Samples of the esophagus, stomach, liver, pyloric blind and intestines were obtained. An anatomical and histological description was performed. The digestive canal presented a short tubular esophagus, a slightly dilated, J-shaped stomach and thick walls. The stomach had a cardiac region that ended in a pyloric sphincter from which the intestine of thin walls. The intestine presented an anterior, middle and posterior segment. The anterior region of the first segment of the middle intestine presented 4-5 pairs of pyloric cecum. The middle intestine represented approximately $30 \%$ of the total length of the digestive canal, with a smaller diameter compared to the first segment. The posterior intestine was separated from the middle intestine by a thick and powerful sphincter. The liver was large and elongated, and located in the peritoneal cavity located to the left plane and ventral to the swim bladder. The gallbladder was located lateral to the hepatic anterior wolf. The bile duct led to the duodenal region of the anterior intestine. Ventrally, the rectum ended in the anus, located in front of the anal fin. In general, the histological structures were variable according to the segment studied, a mucous tunic was recognized that presented a simple columnar epithelium, a lamina propria composed of loose connective tissue, a muscular layer of the mucosa composed of smooth muscle tissue and a submucosal layer composed of loose connective tissue, a circular and longitudinal stratum of muscular tunic, which had striated musculature and an adventitial tunic composed of a simple squamous epithelium. In conclusion, Golden kingklip (Genypterus blacodes) presents a digestive system typical of a carnivorous benthic fish adapted to feed on fish and crustaceans.

KEY WORDS: Golden Kingklip; Digestive Canal; Stomach; Intestine; Teleost; Fish.

\section{INTRODUCTION}

The overexploitation of marine resources has been a constant problem in recent decades in the worldwide, in fact, in Chile currently $72 \%$ of the main fisheries collapsed (Servicio Nacional de Pesca, 2016). Due to this situation, aquaculture emerges as a sustainable alternative for productive diversification, fulfilling an important role in the achievement of food security and in boosting the economic development of coastal areas (Food and Agriculture Organization of the United Nations, 2016). Among the diverse Chilean native species with the potential to be cultivated, Golden kingklip (Genypterus blacodes) has shown to be an excellent candidate (Silva, 2011). G. blacodes is a demersal carnivorous species of an average length of 80 $\mathrm{cm}$ found in depths between 100 and 800 meters associated with rocky substrates (Tascheri et al., 2003; Paredes \& Bravo, 2005). This species is considered as a culinary delicacy with high international demand, reaching prices of US $\$ 3.5 /$ $\mathrm{kg}$ and US $\$ 4.2 / \mathrm{kg}$ for fresh and frozen products respectively (Servicio Nacional de Pesca).

Currently, studies on G. blacodes are focused on solving scientific-technological gaps that allow the scaleup production of this species. In this matter, the lack of knowledge concerning the nutritional requirement has been

\footnotetext{
${ }^{1}$ Institute of Biology, Faculty of Sciences, Pontificia Universidad Católica de Valparaíso, Valparaíso, Chile.

${ }^{2}$ Centro de Investigaciones Costeras, Universidad de Atacama, Copiapó, Chile.

${ }^{3}$ Quillaipe Experimental Station, Fundación Chile, Puerto Montt, Chile.

${ }^{4}$ Center for Applied Biological Research (CIBA), Puerto Montt, Chile.

FUNDING: This study has been financed by CORFO (Corporación de Fomento de la Producción, Chile) in the frame of the project INNOVA $2012-16173$.
} 
identified as one of the main biological limitations to be solved (Silva). Studies on feeding behavior of this species have shown that it feeds on pelagic organisms such as small crustaceans, fish and cephalopods (Tascheri et al.; Dunn et al., 2010). However, despite the relevant information provide for these studies on establishing the dietary preferences of the species, knowledge of the normal anatomical structures of the digestive tract is essential for the determination of specific nutritional requirements of fish species at different stages of life and, therefore, phases of the productive cycle (Serrano et al., 2014).

Several authors (Hellberg \& Bjerkås, 2000; Lokka et al., 2013; Serrano et al.) have described and studied the anatomo-physiological characteristics of the digestive system of fish to better understand their nutritional dynamics. The digestive tract of carnivorous fish consists in a tubular structure of variable diameter that is divided longitudinally into the esophagus, stomach, intestine and rectum. Each segment of the digestive tract performs a specific function, which have a high degree of morphological specialization with the purpose of achieving greater efficiency in secretion, absorption and digestive functions (Buddington \& Diamond, 1987). The oral and oropharyngeal cavities play an important role in the identification, selection, capture and seizure of food items, while the esophagus, stomach and intestine are responsible for the transport, storage, digestion and absorption of nutrients. Nevertheless, among the different fish species there are morphological and functional differences of the digestive tract, suggesting the need of more detailed studies in order to understand the mechanisms and processes involved in obtaining, assimilating and metabolizing nutrients (Buddington \& Diamond; Horn, 1998). Consequently, given the importance of G. blacodes for Chilean aquaculture diversification, the objective of the present study is to describe the normal morphology of the digestive canal (canalis digestorius) of this species, providing a uniform nomenclature and basic information to support its nutritional management in captive conditions.

\section{MATERIAL AND METHOD}

Fish and samples. Twelve specimens of G. blacodes were collected by longline gear at 250-300 m depth in the Quillaipe bay at Lagos Region, Chile (41³3'20.6"S 7243'58.8"W). Each specimen of $G$. blacodes was sacrificed using an overdose of $>250 \mathrm{mg} / \mathrm{l}$ of benzocaine (Kalmagin $20 \%$ ) and labeled with a microchip for identification at the time of collecting the samples at the Quillaipe Necropsy Laboratory of Fundación Chile. Images were captured using a Canon Rebel T3i camera. The GT was dissected, opened and rinsed in $0.9 \% \mathrm{NaCl}$ physiological solution. It was subsequently fixed in $10 \%$ phosphate buffered formalin for $24 \mathrm{~h}$. Then, samples of esophagus, stomach, liver, pyloric cecum and intestines were obtained. Subsequently, they were cut into $0.5 \mathrm{~cm}$ longitudinal sections using a sterile scalpel.

Tissue processing. Sections of esophagus, stomach, pyloric caeca, intestines and liver were obtained and fixed in $4 \%$ formaldehyde for $24 \mathrm{~h}$ at room temperature $\left(22^{\circ} \mathrm{C}\right)$. Then, they were dehydrated in a series of alcohols, clarified in xylol and embedded in Paraplast (Paraplast Plus embedding medium; melting point: $54^{\circ} \mathrm{C}$; Sigma-Aldrich Chemical Co., St Louis, MO, USA). Serial sections were made, $5 \mathrm{~mm}$ thick, with a motorized rotary microtome Leica RM2255 (Leica Microsystems, Switzerland). Subsequently, the sections were rehydrated, immersed in xylol $(10 \mathrm{~m})$, exposed to descending concentrations of ethanol $(100 \%, 96 \%, 80 \%$ and $70 \%$, all $15 \mathrm{~s}$ ) and finally distilled water. Sections of each sample were routinely stained with hematoxylin and eosin and were covered with Entellan mounting medium (Merck, Darmstadt, Germany) and a glass cover slip. Digital photomicrographs of each tissue sample were obtained using a Leica®DM750 optical microscope equipped with a Leica®MC170HD digital camera. A histological evaluation at 40X was performed.

\section{RESULTS}

Gross morphology. The digestive canal of the G. blacodes consisted of a short tubular esophagus, with firm and thick walls that continued without a clear and defined region of transition to a slightly dilated stomach, with a J-shape and thick walls. The length of the esophagus and stomach comprised approximately $40 \%$ of the total length of the digestive canal. The stomach had a muscular lamina, which is particularly thick at the level of the pyloric sphincter. Possibly, according to diet, shape and size were variable among individuals studied, The stomach presented a cardiac region which ended in a pyloric sphincter from which the thin-walled intestine was directed towards the cranial (Fig. 1). The intestine is longer and rectum than the stomach; and his muscular tunic is thinner. It presented a middle and posterior segment. The middle intestine turned slightly to the right of the abdominal cavity and continued in the caudal direction. The anterior region of the first segment of the middle intestine presented 4-5 pairs of pyloric blind, representing 30 $\%$ of the total length of the digestive canal. The second segment of the midgut (without pyloric blinds) shifted to caudal and represented approximately $30 \%$ of the total length of the digestive canal, with a smaller diameter compared to the first segment. No blood vessels were observed in intestinal serous 


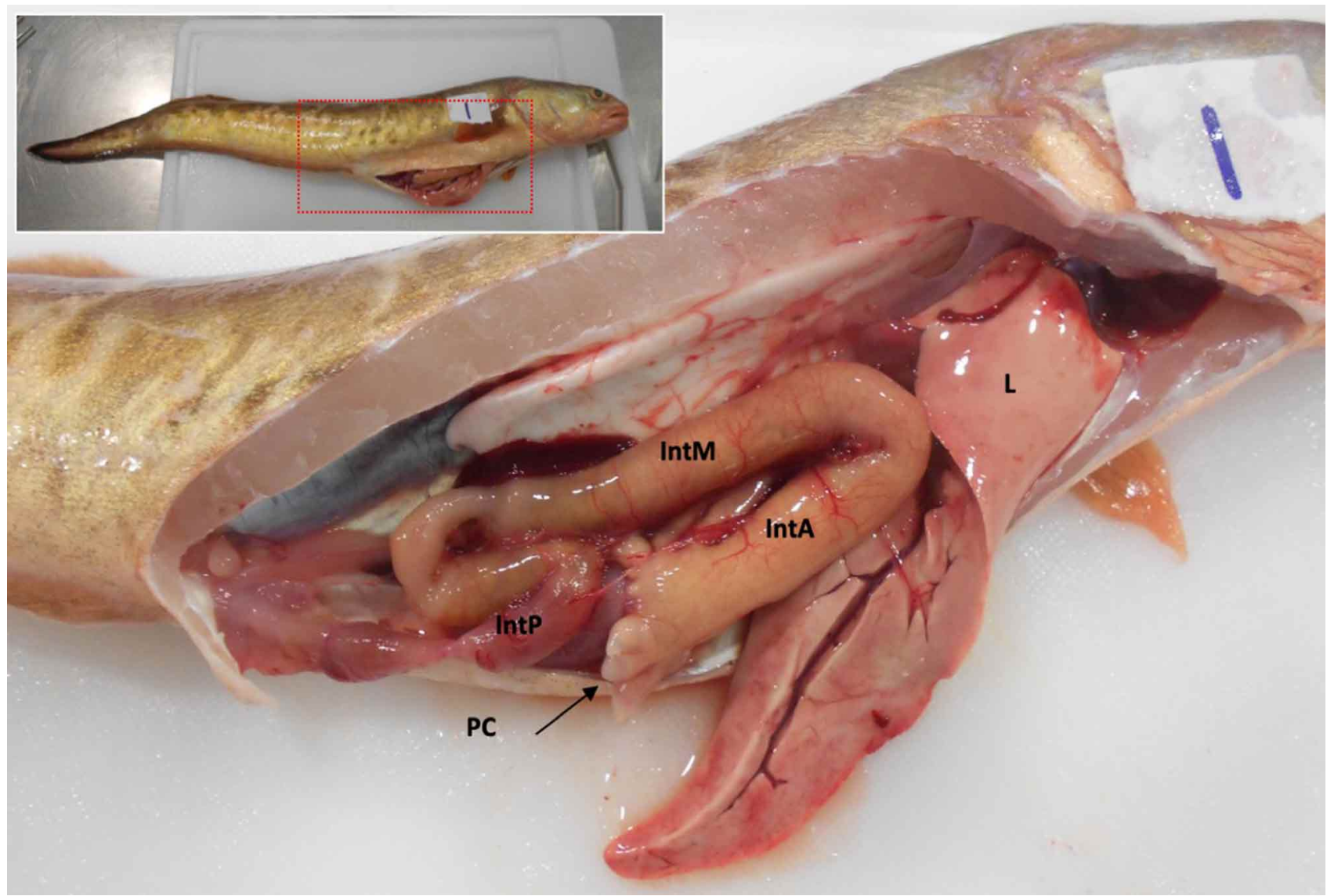

Fig. 1. Gross anatomy of the digestive canal of Golden kingklip (Genypterus chilensis). Right side view. IntA, first segment of the anterior-intestine with pyloric caeca (PC). IntM, first segment of the mid-intestine posterior to pyloric caeca. IntP, posterior segment. The oesophagus, pyloric part of stomach, and the pyloric sphincter are not indicated.

tunica. The posterior intestine separated from the middle intestine by a thick and powerful sphincter. The liver was large and elongated, and located in the peritoneal cavity moved to the left plane and ventral to the swim bladder, it presented a convex and smooth parietal face, and a concave visceral face. Both faces converged in sharp and free margins. In addition, anterior, appendicular and posterior lobes were observed. The gallbladder hangs from the back of the anterior lobe and opens in the bile duct that ends in the duodenal region of the anterior intestine. Ventrally, the rectum ends at the anus, located in front of the anal fin.

Histology. In general, GT presented a digestive canal which was constituted by: esophagus, stomach, pyloric cecum and intestines. In addition, there were accessory digestive glands, such as liver and a pancreas (not described). In general, the histological structures were variable depending on the segment studied, they were recognized i) a mucous tunic (tunica mucosa): which presented a simple columnar epithelium, a lamina propia of the mucosa (lamina propria) composed of loose connective tissue (textus connectivus laxus), a muscular layer of the mucosa (lamina muscularis mucosae) composed of smooth muscle tissue and a submucosal layer (tela submucosa) composed of loose connective tissue, ii) a circular (stratum circulare) and longitudinal (stratum longitudinale) stratum of muscular tunic (tunica muscular), which had striated musculature and iii) a adventitial tunic (tunica adventitia) composed of a simple squamous epithelium . In the esophagus (Fig. 2A), the lamina propia of the mucosa presented a stratified epithelium and the submucosal layer a dense connective tissue with abundant fibroblasts. The muscular tunic had a robust and well-defined circular (external) and a longitudinal (internal) stratum that extended into the submucosa, both strata had striated (myofibra striata) and smooth (myocytus levis) muscle fibers. The transition from the esophagus to the stomach (gaster) was clearly discernible through the change of epithelium to a simple columnar with mucous cells (epitheliocytus gastricus) whose nucleus was located in the basal region of the cell cytoplasm, with mucous content in the apical region and the presence of gastric glands (glandula gastrica propria). The stomach (Fig. 2B) had wide folds (plica gastrica). In the basal region of each gastric fold of the tunica mucosa, the gastric glands were a polygonal shape, opening 

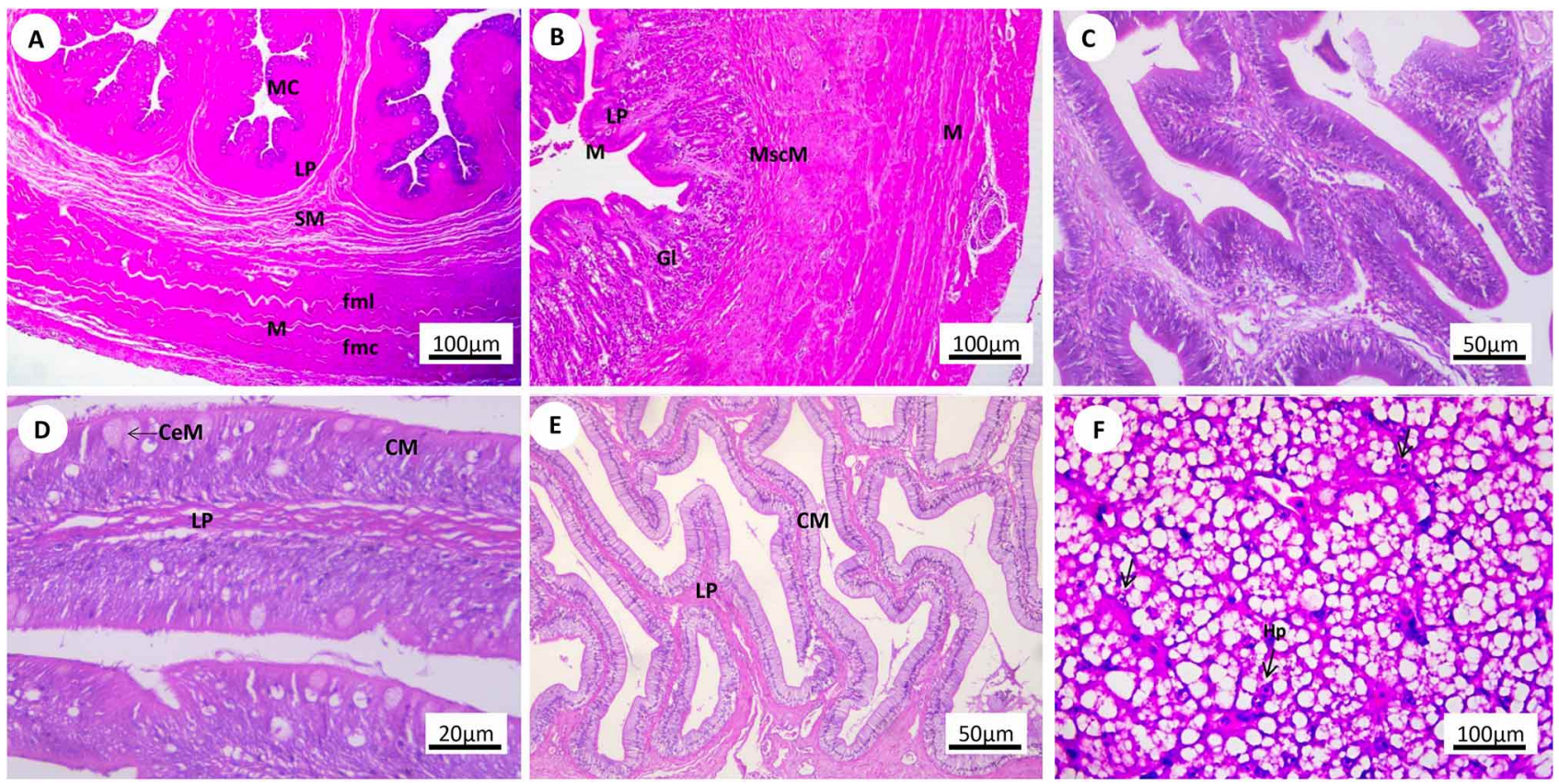

Fig. 2. Histology of the digestive canal of Golden kingklip (Genypterus chilensis). A, Esophagus, mucous tunic (MC) lined by a stratified epithelium, numerous folds and moderate number of mucous cells and the lamina propria (LP) are observed. The submucosal layer (SM) formed by loose connective tissue. Muscle layer (M) formed by external circular (fmc) and internal longitudinal (fml) stratum. B, Stomach, mucous tunic (M) lined by a simple epithelium folded with mucous cells, lamina propria (LP) with numerous gastric glands (Gl), muscular layer of the mucosa (MscM). Muscle layer (M) with an internal layer formed by longitudinal fibers and an internal layer formed by circular fibers. C, Pyloric cecum. A mucous layer formed by columnar epithelium is observed, with a small number of mucous cells, a thin lamina propria is observed in the folds. D, Anterior intestine, mucous tunic (CM) formed by columnar epithelium, with the presence of moderate amount of large mucous cells $(\mathrm{CeM})$. A thin lamina propria (LP) is observed. E, Middle intestine, villi in the mucous tunic (CM) formed by columnar epithelium with a small amount of small mucous cells. A thin lamina propria (LP) of the villi is observed. F, Liver, polygonal hepatocytes, fatty degener ation is observed. Hematoxylin and Eosin staining.

towards the mucous folds, and a thin muscular layer of the mucosa (lamina muscularis mucosae). The submucosal layer presented abundant blood vessels. In addition, a thick muscular tunic was observed, which presented a circular layer (external and thick) and a well-circumscribed longitudinal (internal and thin) layer. Both strata have striated (myofibra striata) and smooth (myocytus levis) muscle fibers. A Pyloric cecum (Fig. 2C) presented a mucous layer formed by columnar epithelium, with a small number of mucous cells, also, a thin lamina propria is observed in the folds. The anterior (Fig. 2D) and middle (Fig. 2E) intestine presented prominent folds (plica) and intestinal villus (villus intestinalis). The mucous tunic was thick and lined with simple columnar epithelium, formed especially by epitheliocytes (columnaris epitheliocytic villi). In addition, a moderate amount of large mucous cells was observed. The lamina propria of the mucosa was observed thin and the folds presented a thin layer of connective tissue between the base and the compact stratum (stratum compactum mucosae). In the posterior intestine moderately sized folds and villi were observed. The mucous tunic was thick, it was formed by a stratified columnar epithelium with few large mucous cells. A thin submucosal layer was observed, especially between the base of the folds and the compact layer of the mucosa. In liver (hepar; Fig. 2F) polygonal cells of different sizes were observed, which presented central nuclei and, in some cases were peripherally displaced. The bile ducts (canaliculus bilifer) showed a columnar epithelium, consisting of high prismatic cells. In addition, the presence of star macrophages (macrophagocytus stellatus) was observed as part of the sinusoid walls.

\section{DISCUSSION}

There is limited knowledge regarding the digestive system of G. blacodes. This study provides detailed information about the macroscopic and microscopic morphology of the GT. Different sections of the stomach and digestive canal were studied. This information is useful to understand eating habits and consequently to propose morphological responses to physiological, pathological and immunological problems that are related to the evaluation of diets or treatments. 
The esophagus of $G$. blacodes is a short and straight tube with a large amount of muscle tissue, that connects the mouth to the stomach. Interestingly, the length of this organ, associated only with the passage of food, is similar to those found in stomach less fish, such as lampreys, in which the esophagus is directly connected to the intestine (Stevens \& Hume, 1995). The epithelial lining and extensive longitudinal folds suggest an effortless swallowing of food items. The stratified epithelium would play a protective role against abrasion, mechanical stress and also an osmoregulatory function (Hellberg \& Bjerkås). Our study also revealed the presence of cilia that cover the esophagus epithelium. This suggests a role in the movement of food particles, and prevents injuries when solid particles pass through the lumen, similar morphology has been described in eels (Abaurrea-Equisoain \& Ostos-Garrido, 1996). Moreover, esophagus epithelium of G. blacodes presented a considerable number of mucous cells, which have been commonly described in the postgastric mucosa of teleost fish. These cells produce a mucoid substance that not only has immune functions (against bacterial infection; Humbert et al., 1984) and osmoregulators, but they are also important for the rapid and uniform lubrication of food particles along entire esophagus during swallowing (Albrecht et al., 2001). The thick striated muscular layer observed on $G$. blacodes esophagus provides protection, flexibility and strength for swallowing large prey (Domeneghini et al., 1998). Cao \& Wang (2009) affirm that this type of musculature allows rejection of the food ingested, when it is not palatable and also helps to push food to the stomach under a voluntary control. G. blacodes presents a Jshaped stomach, which has also been described in other carnivorous fish (Clarke \& Witcomb, 1980). This anatomical shape allows a better distension capacity, and therefore, the intake and storage of large amounts of food. The findings in the present study showed that the stomach of G. blacodes is divided into the cardiac, fundic, and pyloric regions. The thick muscular layer suggests the presence of a strong crushing mechanism of the food prior to its passage to the intestine. The presence of gastric glands in the stomach indicates that it could synthesize gastric acids with digestive enzymes. These mentioned features have also been described in Salmo salar (Lokka et al.), Esox lucius (Bucke, 1971) Anguilla anguilla (Clarke \& Witcomb) and Anarhichas lupus (Hellberg \& Bjerkås). In most carnivorous fish, the main feature of the pyloric region is the presence of the pyloric sphincter and thicker lamina muscularis mucosae, both plays a role in mixing and regulating the flow of partially digested food from the stomach to the intestine (Albrecht et al.). This later pattern was also observed in our study, suggesting the need to control the gastric evacuation rate due to the nutritional complexity of food items such as crustaceans and other fish species. Furthermore, the presence of a large number of gastric glands observed in G. blacodes is consistent with the feeding habits of this species, which are associated with the digestion of protein-rich preys (Machado et al., 2013). The intestine of G. blacodes consists of a tubular organ similar to those found in terrestrial vertebrates, which is morphologically divided into pyloric caeca, an anterior and a posterior region (Kardong, 2009; Canan et al., 2012). The presence of the pyloric caeca has been considered an evolutionary adaptation to facilitate the digestive process, by increasing the area of nutrient absorption (Canan et al.). There are reports that they play a role in enzymatic decomposition and in the absorption of glucose, amino acids and peptides (Buddington \& Diamond; Bakke-McKellep et al., 2000). Other functions such as food deposits, stomach supplements and areas of bacterial degradation have also been suggested, similar to what occurs with food in the pyloric caeca of mammalian. In the current study, the pyloric caeca showed small folds with a clear longitudinal orientation with respect to the axial axis of the caeca, this organization could facilitate transport within this structure. Regarding the mucous cells, although they were scarce in the epithelium, their presence would indicate an additional role of the pyloric caeca with respect to mucus secretion, It was also possible to observe a thickening of the stratified columnar epithelium tissue in the folds, similar to that reported in salmon (Løkka et al., 2013). The anterior and a posterior intestine of $G$. blacodes showed macroscopic differences, displaying a larger diameter of the anterior region compare to the posterior region. Nevertheless, no histological differences were observed regarding the layers in the wall between these regions. The arrangement of the simple columnar epithelium is similar to that described previously in most teleost fish (Kardong). This pattern in the organization reveals a highly absorbent surface and is usually associated with the presence of a functional stomach. Moreover, morphological observations of the anterior intestine of $G$. blacodes showed longer folds covered with a larger number of mucous cell and microvilli, which would indicate that this region, together with the stomach, concentrates most of the digestive and enzymatic function of the GT. Similar results were described in other teleost, where nutrient absorption occurs primarily in the foregut and pyloric caeca (Buddington \& Diamond; Bakke-McKellep et al.).

In conclusion, Golden kingklip ( $G$. blacodes) presents a digestive system typical of a carnivorous benthonic fish adapted to feed on fish and crustaceans. The canalis digestorius of this fish species showed a short esophagus, Jshaped stomach and pyloric caeca that was constituted by mucous, submucosal, muscular and serous tunic layers. The anterior and middle regions of the intestine are more active in nutrient absorption. Therefore, formulation and manufacturing of artificial feed for $G$. blacodes should consider high levels of protein, probably of marine origin, and low levels of lipids. Furthermore, the observations 
described in this study are useful as a reference for research related to the effect of environmental factors, drugs, stress and diet on the digestive system of this fish species. Future nutri-physiological or genomic studies may also potentially benefit from morphological information.

SALINAS, P.; SERRANO, E.; SÁNCHEZ, J. C. \& GODOY, M. Caracterización Anatómica e histológica del canal digestivo del congrio dorado (Genypterus blacodes). Int. J. Morphol., 38(3):677-682, 2020.

RESUMEN: Dada la importancia del Congrio colorado (Genypterus blacodes) como alternativa a la producción de especies salmonídeas para la diversificación mundial de la acuicultura, el objetivo del presente estudio es describir la morfología normal del canal digestivo de esta especie, proporcionando una nomenclatura uniforme e información básica para apoyar su manejo nutricional en condiciones de cautiverio. Doce especímenes silvestres fueron colectados y disecados. Se obtuvo muestras del esófago, estómago, hígado, ciego pilórico e intestinos. Se realizó una descripción anatómica e histológica. El canal digestivo presentó un esófago tubular corto, un estómago ligeramente dilatado, con forma de $\mathrm{J}$ y paredes gruesas. El estómago presentaba una región cardíaca que terminaba en un esfínter pilórico desde el cual el intestino de paredes delgadas. El intestino presentaba un segmento anterior, medio y posterior. La región anterior del primer segmento del intestino medio presentó 4-5 pares de ciegos pilóricos. El intestino medio representó aproximadamente el $30 \%$ de la longitud total del canal digestivo, con un diámetro menor en comparación con el primer segmento. El intestino posterior estaba separado del intestino medio por un esfínter grueso y poderoso. El hígado era grande y alargado, y ubicado en la cavidad peritoneal ubicado al plano izquierdo y ventral a la vejiga natatoria. La vesícula biliar se ubicó lateral al lobo anterior hepático. El ducto biliar desembocó en la región duodenal del intestino anterior. Ventralmente, el recto terminó en el ano, ubicado frente a la aleta anal. En general, las estructuras histológicas fueron variables según el segmento estudiado, se reconoció una túnica mucosa que presentaba un epitelio columnar simple, una lámina propia de la mucosa compuesta por tejido conectivo laxo, una capa muscular de la mucosa compuesta por músculo liso tejido y una capa submucosa compuesta de tejido conectivo laxo, un estrato circular y longitudinal de túnica muscular, que tenía musculatura estriada y una túnica adventicia compuesta por un epitelio plano simple. En conclusión, Congrio colorado (Genypterus blacodes) presenta un sistema digestivo típico de un pez bentónico carnívoro adaptado para alimentarse de peces y crustáceos.

PALABRAS CLAVE: Congrio Dorado; Canal Digestivo; Estómago; Intestino; Teleósteos; Peces.

\section{REFERENCES}

Abaurrea-Equisoain, M. A. \& Ostos-Garrido, M. V. Cell types in the esophageal epithelium of Anguilla anguilla (Pisces, Teleostei). Cytochemical and ultrastructural characteristics. Micron, 27(6):419-29, 1996.

Albrecht, M. P.; Ferreira, M. F. N. \& Caramaschi, E. P. Anatomical features and histology of the digestive tract of two related neotropical omnivorous fishes (Characiformes; Anostomidae). J. Fish Biol., 58(2):419-30, 2001.

Bakke-McKellep, A. M.; Nordrum, S.; Krogdahl, Å. \& Buddington, R. K. Absorption of glucose, amino acids, and dipeptides by the intestines of Atlantic salmon (Salmo salar L.). Fish Physiol. Biochem., 22:33-44, 2000.

Buddington, R. K. \& Diamond, J. M. Pyloric ceca of fish: A "new" absorptive organ. Am. J. Physiol., 252(1 Pt. 1):G65-76, 1987.
Canan, B.; do Nascimento, W. S.; da Silva, N. B. \& Chellappa, S. Morphohistology of the digestive tract of the damsel fish Stegastes fuscus (Osteichthyes: Pomacentridae). ScientificWorld Journal, 2012:787316, 2012.

Cao, X. J. \& Wang, W. M. Histology and mucin histochemistry of the digestive tract of yellow catfish, Pelteobagrus fulvidraco. Anat. Histol. Embryol., 38(4):254-61, 2009.

Clarke, A. J. \& Witcomb, D. M. A study of the histology and morphology of the digestive tract of the common eel (Anguilla anguilla). J. Fish Biol., 16(2):159$70,1980$.

Domeneghini, C.; Pannelli Straini, R. \& Veggetti, A. Gut glycoconjugates in Sparus aurata L. (Pisces, Teleostei). A comparative histochemical study in larval and adult ages. Histol. Histopathol., 13(2):359-72, 1998.

Dunn, M. R.; Connell, A. M.; Forman, J.; Stevens, D. W. \& Horn, P. L. Diet of two large sympatric teleosts, the ling (Genypterus blacodes) and hake (Merluccius australis). PLoS One, 5(10):e13647, 2010.

Food and Agriculture Organization of the United Nations (FAO). The State of World Fisheries and Aquaculture (SOFIA). Rome, Food and Agriculture Organization of the United Nations, 2016.

Hellberg, H. \& Bjerkås, I. The anatomy of the oesophagus, stomach and intestine in common wolffish (Anarhichas lupus L.): a basis for diagnostic work and research. Acta Vet. Scand., 41(3):283-97, 2000.

Humbert, W.; Kirsch, R. \& Meister, M. F. Scanning electron microscopic study of the oesophageal mucous layer in the eel, Anguilla anguilla L. J. Fish Biol., 25(1):117-22, 1984.

Kardong, K. V. Vertebrates: Comparative Anatomy, Function, Evolution. Boston, McGraw-Hill Higher Education, 2009.

Løkka, G.; Austbø, L.; Falk, K.; Bjerkås, I. \& Koppang, E. O. Intestinal morphology of the wild atlantic salmon (Salmo salar). J. Morphol., 274(8):859-76, 2013

Machado, M. R. F.; de Oliveira Souza, H.; de Souza, V. L.; de Azevedo, A.; Goitein, R. \& Nobre, A. D. Morphological and anatomical haracterization of the digestive tract of Centropomus parallelus and C. undecimalis. Acto Sci., Biol. Sci., 35(4):467-74, 2013.

Paredes, F. \& Bravo, R. Reproductive cicle. Reproductive cycle, size at first maturation and fecundity in the golden ling, Genypterus blacodes, in Chile. N. Z. J. Mar. Freshw. Res., 39(5):1085-96, 2005.

Serrano, E.; Leiva, C.; Lonza, C.; Sánchez, J. C.; Wacyk, J.; Zegers, T. \& Godoy, M. Histological and morphological characterization of the digestive tract of southern hake (Merluccius australis). Int. J. Morphol., 32(3):1079-84, 2014.

Servicio Nacional de Pesca (SERNAPESCA). Anuario estadístico de pesca 2016. Valparaíso, Servicio Nacional de Pesca, Gobierno de Chile, 2016. Available from: http://ww2.sernapesca.cl/ index.php?option=com_content $\&$ task=view $\&$ id $=2303 \&$ Itemid $=889$

Silva, K. Estado de las potenciales especies para diversificar la acuicultura. Mundo Acuic., 82:6-8, 2011.

Stevens, C. E. \& Hume, I. D. General Characteristics of the Vertebrate Digestive System. In: Stevens, C. E. \& Hume, I. D. (Eds.). Comparative Physiology of the Vertebrate Digestive System. $2^{\text {nd }}$ ed. Cambridge, Cambridge University Press, 1995.

Tascheri, R.; Sateler, J.; Merino, J.; Díaz, E.; Ojeda, V. \& Montecinos, M. Estudio biológico-pesquero de congrio colorado, congrio negro y congrio dorado en la zona centro-sur. Valparaíso, Instituto de Fomento Pesquero, Informe Final FIP 2001-15, 300, 2003.

Corresponding author:

Dr. Paulo Salinas

Institute of Biology - Faculty of Sciences

Pontificia Universidad Católica de Valparaiso

Valparaiso- CHILE

Email: paulo.salinas@pucv.cl

Received: 23-10-2019

Accepted: 27-12-2019 